\title{
Characteristics of a High Molecular Weight Extracellular Protein of Streptococcus mutans
}

\author{
By HENRY FORESTER, * NEIL HUNTER AND KENNETH W. KNOX \\ Institute of Dental Research, United Dental Hospital, Chalmers Street, Sydney NSW 2010, \\ Australia
}

(Received 6 April 1983)

\begin{abstract}
A high molecular weight protein antigen, designated $\mathrm{P} 1$, has been isolated from the culture fluid of chemostat-grown Streptococcus mutans strain Ingbritt and shown to be free of other antigens including glucosyltransferase. Antiserum against the protein was used in rocket immunoelectrophoresis to confirm and extend the previous observation that there were major differences in the amount of the protein produced under different growth conditions. Physico-chemical and serological studies indicated that protein $\mathrm{P} 1$ was indistinguishable from antigens $\mathrm{B}, \mathrm{I} / \mathrm{II}$ and IF isolated in other laboratories. Mammalian tissue cross-reactivity of protein P1 was demonstrated by binding of antiserum to Pl to sections of normal rabbit tissues, particularly heart. There was also a statistically significant increase in the number of mononuclear leucocytes in heart tissue of rabbits which had been injected with protein P1, when compared with the levels in control uninjected rabbits; injection with whole cells of $S$. mutans Ingbritt did not produce this effect.
\end{abstract}

\section{INTRODUCTION}

Several cell-surface and extracellular proteins of oral streptococci have been implicated in dental caries through their role in plaque formation. These include glucosyltransferase (GTF) and fructosyltransferase, which produce extracellular glucans and fructans, respectively, from sucrose (Russell, R. R. B., 1979 a; Fukui et al., 1982; Carlsson, 1970), and proteins mediating adherence of Streptococcus mutans and Streptococcus sanguis to the pellicle-coated tooth surface (Liljemark \& Schauer, 1975; McCabe et al., 1977). Other proteins have been identified serologically, though their functions remain to be defined. These include several from $S$. mutans serotype $c$ from which one group isolated four proteins designated antigens I, II, III and IV (Russell, M. W. \& Lehner, 1978) and an independent group referred to four proteins which they isolated as antigens A, B, C and D (Russell, R. R. B., 1979b; Russell, R. R. B. et al., 1982, 1983). The potential importance of such cell-surface proteins was indicated by studies showing that treatment of cell-wall fractions with proteases resulted in a loss of their ability to protect immunized monkeys against dental caries (Colman \& Cohen, 1979).

Although several streptococcal components have been examined in animal studies as potential vaccines against caries (McGhee \& Michalek, 1981), the studies on primates have concentrated on the above-mentioned antigens I-IV and A-D. Proteins I and II are products of a single antigen designated I/II (Russell, M. W. et al., 1980), which is derived from the bacterial cell wall (Zanders \& Lehner, 1981), and which has been shown to be highly effective in reducing the amount of dental caries in immunized monkeys (Lehner et al., 1980). Antigen III was shown to be less effective (Lehner et al., 1982), while no information is available about antigen IV. Antigens A and B have been isolated (Russell, R. R. B., 1979b), and also examined for their efficacy in caries vaccination. While earlier studies pointed to antigen $\mathrm{B}$ providing

\footnotetext{
Ahbretiations: DBP, dextran-binding protein: GTF, glucosyltransferase; IEF, iso-electric focusing: LTA, lipoteichoic acid; RIE, rocket immunoelectrophoresis.
} 
protection (Russell, R. R. B. et al., 1982), later studies have shown that antigens A and C are more effective (Russell, R. R. B. et al., 1983). Antigen B is also indistinguishable from another antigen, designated IF, for which there was evidence of an immunological cross-reactivity with a human heart tissue component (Russell, R. R. B., $1979 b$; Hughes et al., 1980; Hughes, 1981).

Studies in this laboratory of the amounts of extracellular protein of chemostat-grown $S$. mutans Ingbritt (serotype $c$ ) indicated that one (P1), which showed marked variation in amount under different growth conditions, had physical properties similar to those reported for antigens B (Russell, R. R. B., 1979 b) and I/II (Russell, M. W. et al., 1980). Further, the results of preliminary tests indicated that P1 was serologically similar to antigen B (Hardy et al., 1981). Because of the potentially important biological properties of this protein, its purification free from contamination by other antigens was undertaken. Specific antiserum was produced in rabbits in order to compare the levels of $\mathrm{P} 1$ in chemostat culture fluids by rocket immunoelectrophoresis (RIE) with data obtained by quantitative SDS-PAGE (Hardy et al., 1981). In addition, the antiserum was used to enable a direct serological examination of the various protein preparations from the different laboratories; these were also compared for their physical properties. Finally, the tissues of the injected rabbits were examined for adverse effects and for evidence of a component reacting with antiserum to $\mathrm{P} 1$.

\section{METHODS}

Growth of $S$. mutans Ingbritt. Organisms were grown in continuous culture with limiting sucrose $(0 \cdot 5 \%$, w/v) at pH 6.0 and a dilution rate $(D)$ of $0.5 \mathrm{~h}^{-1}$, and harvested (Jacques et al., 1979a,b; Hardy et al., 1981). Growth under these conditions gave rise to maximal amounts of protein $\mathrm{P} 1$ and minimal amounts of GTF in the culture fluid, and thus provided suitable starting material for the purification of protein $\mathrm{P} 1$. The culture fluid was concentrated 10fold by using a 10000 Dal exclusion-limit hollow fibre cartridge with a model LC-2 concentrator (Amicon Corp., Lexington, Mass., U.S.A.) and stored at $-20^{\circ} \mathrm{C}$.

Cell wall preparation. Organisms were disrupted in a Braun model MSK homogenizer (Melsungen, F.R.G.), and cell walls were isolated by a hot SDS-washing procedure (Campbell et al., 1978).

Purification of protein P1. The concentrated culture fluid was made $65 \%$ saturated with ammonium sulphate at $20{ }^{\circ} \mathrm{C}$. After $18 \mathrm{~h}$, the precipitate was collected by centrifugation, washed once with $65 \%$ saturated ammonium sulphate, and redissolved in $50 \mathrm{mM}-\mathrm{Tris} / \mathrm{HCl}$ buffer, $\mathrm{pH} 7.5$. Ion-exchange and gel-filtration column chromatography were carried out at $4{ }^{\circ} \mathrm{C}$ in a $90 \times 1.6 \mathrm{~cm}$ column at flow rates of $20 \mathrm{ml} \mathrm{h}^{-1}$ and $12 \mathrm{ml} \mathrm{h}^{-1}$, respectively. Separations were conducted in $50 \mathrm{mM}$-Tris/ $\mathrm{HCl}$ buffer, $\mathrm{pH} 7.5$, and the eluate was monitored with a $278 \mathrm{~nm}$ interference filter. Elution from DEAE-Sephadex A25 was first carried out stepwise with $0 \cdot 1 \mathrm{M}$ and $0.5 \mathrm{M}-$ $\mathrm{NaCl}$, followed by gradient elution when the major fractions were collected at $0 \cdot 08-0 \cdot 13 \mathrm{M}$ and $0 \cdot 14-0 \cdot 23 \mathrm{M}-\mathrm{NaCl}$. The final purification stage involved elution from Sepharose CL-6B.

Monitoring the purity of samples during protein purification. Fractions were analysed for the presence of cell-wall polysaccharide, lipoteichoic acid (LTA), GTF and dextran-binding protein (DBP) by reference to appropriate preparations. Polysaccharide was estimated by the primary cysteine-sulphuric acid method for hexose (Dische, 1955) and the modification that is specific for 6-deoxy-hexose (Gibbons, 1955). LTA was determined by RIE (Jacques et al., 1979b) and confirmed by a modification (H. Forester, unpublished) of the azo dye method for estimating lipopolysaccharide (Janda \& Work, 1971). GTF was estimated by measuring the rate of glucan synthesis (Walker et al., 1980).

The relative amounts of $\mathrm{P} 1, \mathrm{GTF}$ and DBP in different fractions were estimated by SDS-PAGE following previously described procedures (Hardy et al., 1981; Knox et al., 1981).

Physico-chemical characterization of Pl. Analysis by SDS-PAGE and iso-electric focusing (IEF) on Ampholine polyacrylamide gel thin-layer plates, $\mathrm{pH} 4 \cdot 0-6.5$ (LKB, Bromma, Sweden), also followed previously described procedures (Hardy et al., 1981). Protein P1 was compared with antigens I/II and B, the respective preparations kindly being provided by Prof. T. Lehner, Guy's Hospital, London and Dr R. R. B. Russell, Royal College of Surgeons, Downe, Kent, who also supplied the corresponding antisera.

Protein P1 was analysed for its amino acid components following hydrolysis under nitrogen in redistilled $6 \mathrm{M}-$ $\mathrm{HCl}$ at $110^{\circ} \mathrm{C}$ for $24 \mathrm{~h}$ in the Department of Biochemistry, University of Sydney, by Dr M. A. W. Thomas and Mr L. Higginbottom, using a Jeol amino acid analyser, model JLC-6AH (Jeol Inc. Cranford, N. J., U.S.A.).

Serological procedures. Antisera were obtained from male New Zealand white rabbits that had been injected with heat-killed cells of $S$. mutans Ingbritt or Lactobacillus casei NCTC 6375 (Campbell et al., 1978), or with egg white lysozyme (Calbiochem, $3 \times$ crystallized). Lysozyme $(1 \mathrm{mg})$ in Freund's complete adjuvant was injected subcutaneously on three occasions at monthly intervals and serum was collected two weeks later.

Antiserum to protein Pl was obtained by the intramuscular injection into rabbits of $50 \mu \mathrm{g} P 1$ in a mixture of $0.9 \mathrm{ml}$ PBS (0.15 M-phosphate/0.15 M-NaCl, pH 7.4) and $0.1 \mathrm{ml}$ aluminium hydroxide adjuvant (Alu Gel S, Serva); 
five injections were given at three-weekly intervals (Russell, R. R. B., 1979b) and antiserum was collected one week after each injection. The IgG component was obtained by applying the immunoglobulin fraction (Closs et al., 1975) to a column of DEAE-Sephacel (Mollison, 1975).

Protein P1, antigen B and antigen I/II $\left(1 \mathrm{mg} \mathrm{ml}^{-1}\right)$ were compared by immunodiffusion and immunoelectrophoresis $(1 \%$ agarose in $20 \mathrm{mM}$-Tris/barbiturate buffer, $\mathrm{pH} 8 \cdot 6)$ for their reactivity with antiserum to $\mathrm{P} 1$ and also antisera to antigens B (Dr R. R. B. Russell), I/II (Prof. T. Lehner) and IF (kindly supplied by Dr M. Hughes, Wellcome Research Laboratories, Beckenham, Kent).

RIE was employed for the quantification of $\mathrm{P} 1$ in culture fluids available from previous studies on $S$. mutans Ingbritt (Hardy et al., 1981; Knox et al., 1981). The plates for RIE held $0.2 \mathrm{ml}$ of the immunoglobulin fraction of antiserum and $12 \mathrm{ml}$ Agarose $\mathrm{M}$ (LKB) in $20 \mathrm{~mm}$-Tris/barbiturate buffer, $\mathrm{pH} \mathrm{8} \cdot 6$, and were run at $15 \mathrm{~V} \mathrm{~cm}^{-1}$ for $2 \mathrm{~h}$. Samples were assayed in groups according to each variable under investigation (dilution rate, $\mathrm{pH}$ or carbohydrate source), at least in triplicate, and each group of determinations was repeated under identical conditions. Results are expressed as mean rocket height per mg dry wt organisms.

Microscopy of tissue sections. Rabbit tissues were removed, fixed iitPBS containing $4 \%(\mathrm{w} / \mathrm{w})$ formaldehyde, dehydrated in a graded series of ethanol concentrations, cleared in xylol and embedded in paraffin. Sections from control (uninjected) and experimental animals were kindly prepared by Mrs C. Lossin and Miss Z. Benjamin.

For counts of the number of mononuclear leucocytes in heart tissue, $6 \mu \mathrm{m}$ sections were stained with haematoxylin and eosin, coded and evaluated blind. Five random fields were counted at $\times 250$ magnification and the average of the total count for three sections was determined.

For fluorescent antibody studies, $6 \mu \mathrm{m}$ sections of heart valve and muscle, kidney, liver, brain, skeletal muscle and oral mucosa from control (uninjected) rabbits were de-paraffinized through xylol and graded ethanol to water. The IgG fraction of antiserum to protein P1 was applied to sections at both a 10 -fold dilution (equivalent to the antibody level in serum) and a 100-fold dilution. After $1 \mathrm{~h}$ at room temperature, sections were washed three times with cold PBS, and treated with 10-fold diluted sheep anti-rabbit IgG (Wellcome FITC-labelled, IgG fraction). After further washing in PBS, sections were mounted in phosphate-buffered ( $\mathrm{pH} \mathrm{7.4)} \mathrm{glycerol,} \mathrm{examined} \mathrm{with} \mathrm{a}$ Leitz Orthoplan microscope equipped for epi-illumination and photographed.

Control experiments employed antisera to $L$. case $i$ and egg white lysozyme and antiserum to Pl (200 $\mu$ l) that had been absorbed for $1 \mathrm{~h}$ at room temperature with $S$. mutans Ingbritt cell wall $(5 \mathrm{mg})$ in a final volume of $2 \mathrm{ml}$.

\section{RESULTS}

\section{Purification of protein $P I$}

All stages of purification were monitored for the presence of LTA, polysaccharide, GTF and DBP. As determined by SDS-PAGE, protein P1 was quantitatively precipitated by $65 \%$ saturated ammonium sulphate, and nearly all of the LTA and polysaccharide remained in the supernatant fraction. However, as shown in Fig. 1, P1 was only a minor component of the precipitated protein, calculated at $27 \%$ compared with $40 \%$ GTF and $33 \%$ DBP. Subsequent stages in the purification were also monitored by SDS-PAGE (Fig. 1).

Column chromatography of the re-dissolved ammonium sulphate precipitate was performed on DEAE-Sephadex A25 equilibrated with $50 \mathrm{mM}$-Tris/HCl, $\mathrm{pH} \mathrm{7.5}$. Elution (stepwise) with $0.1 \mathrm{M}-\mathrm{NaCl}$ gave a fraction containing $90 \% \mathrm{P} 1$, and this was increased to $95 \%$ by subsequent gradient elution and by collecting the fractions between 0.08 and $0.13 \mathrm{M}-\mathrm{NaCl}$. By this stage polysaccharide and LTA were not detectable, but GTF $(1.7 \%)$ and DBP $(2.9 \%)$ were still present. Subsequent elution from Sepharose CL-6B gave a fraction (Fig. 2a, peak A) which contained less than $0.01 \%$ GTF and DBP. The absence of GTF was confirmed by the lack of ability to synthesize glucan from sucrose. The preparation employed in all subsequent studies was obtained by the further passage of peak A through Sepharose CL-6B (Fig. 2b). A second peak of lower molecular weight was also obtained, and, as this pointed to the possible instability of $\mathbf{P 1}$ in solution, the preparation was stored freeze-dried and only freshly prepared solutions were used.

\section{Characteristics of protein $P 1$}

The protein preparation has an isoelectric point of $5.40 \pm 0.02$ (Fig. $3 a$ ) and a molecular weight on SDS-PAGE of 185000 (Fig. $3 b$ ). These values are very similar to those for antigens B and I/II (Figs $3 a, b$ ). A positive periodate-Schiffs' test provided evidence that $\mathrm{Pl}$ was a glycoprotein (Hardy et al., 1981). 


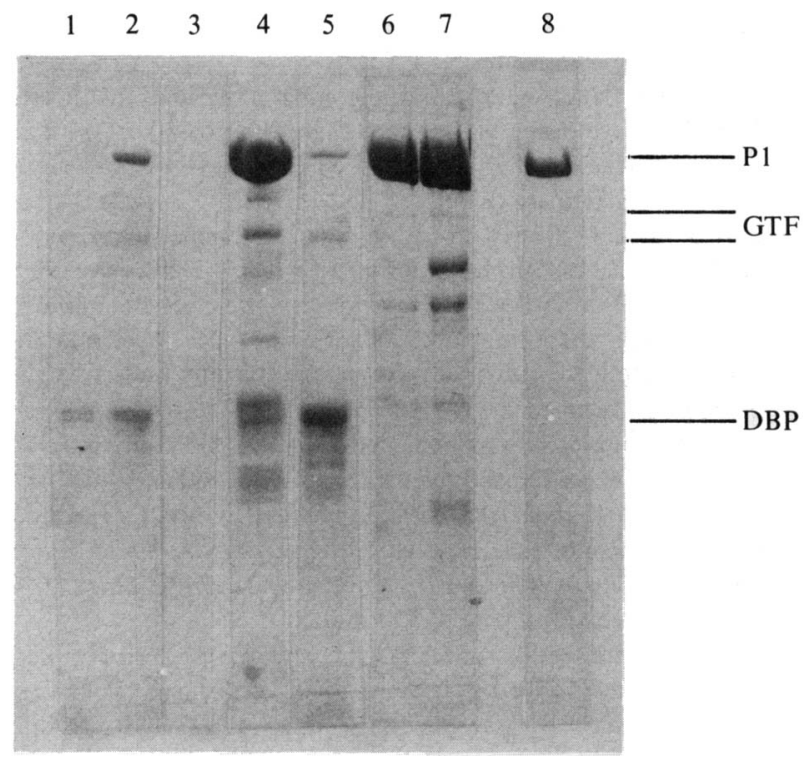

Fig. 1. Analysis by discontinuous SDS-PAGE of fractions obtained during the purification of protein P1. The locations of P1, GTF and DBP were determined by reference to pure samples and the relative levels in each fraction were calculated by scanning microdensitometry of Coomassie blue-stained, dried gels. Samples, which were not adjusted for protein concentration, are: $65 \%$ ammonium sulphate supernatant (1) and precipitate (2); fraction from DEAE-Sephadex A25 eluted stepwise with $50 \mathrm{~mm}$ Tris/ $\mathrm{HCl}(3), 0 \cdot 1 \mathrm{M}-\mathrm{NaCl}(4)$ and $0.5 \mathrm{M}-\mathrm{NaCl}(5)$; gradient elution from DEAE-Sephadex A25 between 0.08 and $0.13 \mathrm{M}-\mathrm{NaCl}(6)$ and 0.14 and $0.23 \mathrm{M}-\mathrm{NaCl}(7)$; protein $\mathrm{Pl}$ obtained following second stage chromatography on Sepharose CL-6B (8).
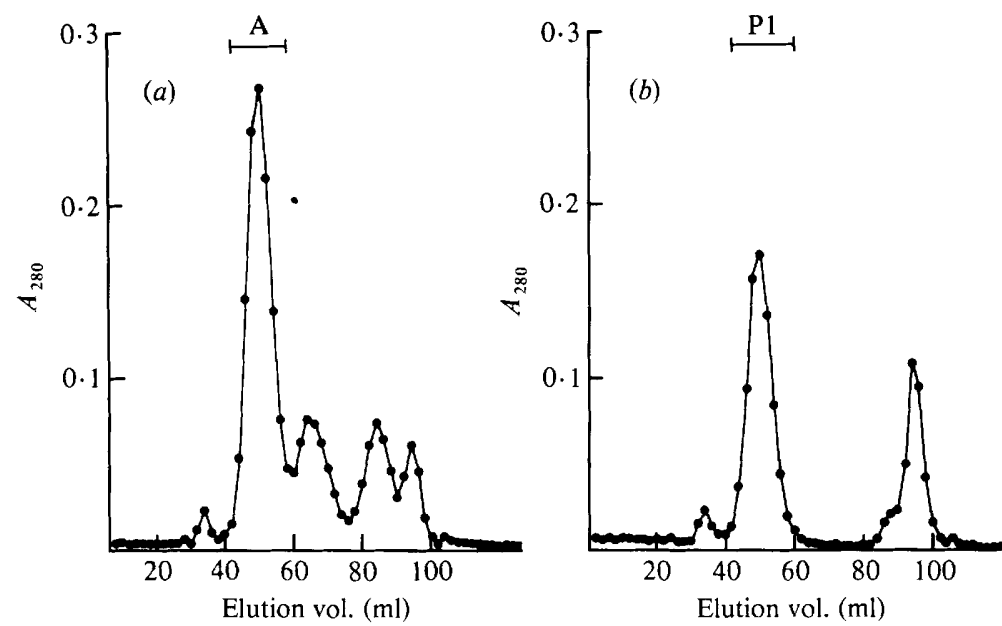

Fig. 2. Final stages in the purification of P1. The eluate from DEAE-Sephadex A25 was applied to Sepharose CL-6B to yield fraction A $(a)$, which was applied to the same column to yield a high molecular weight fraction, $\mathrm{P} 1$, and a lower molecular weight fraction $(b)$. 

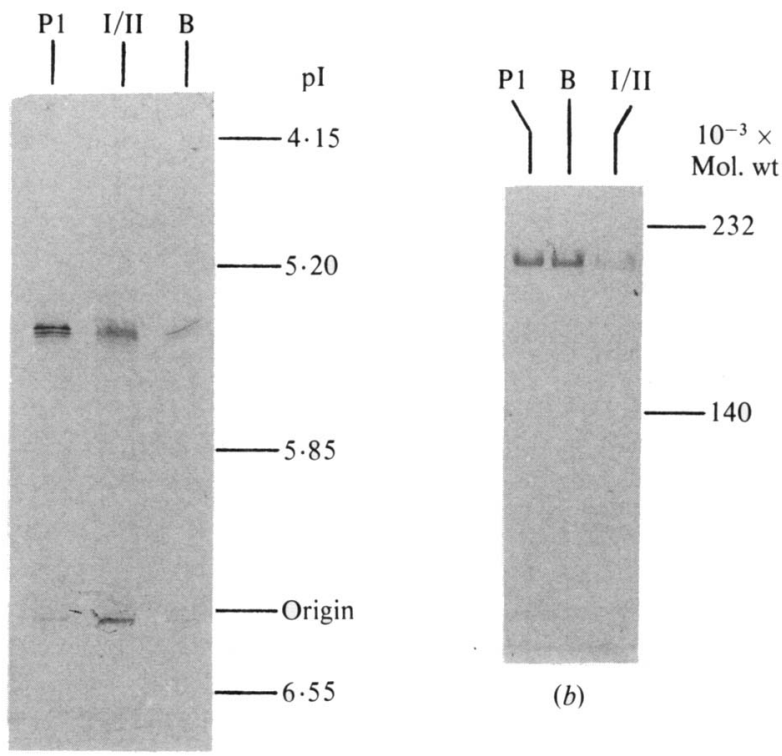

(b)

(a)

Fig. 3. Comparison of protein Pl with antigens B and I/II by: (a) IEF at a concentration of $1 \mathrm{mg} \mathrm{ml}^{-1}$ and (b) SDS-PAGE at an estimated concentration of $1 \mathrm{mg} \mathrm{ml}^{-1}$ for $\mathrm{P} 1,4.5 \mathrm{mg} \mathrm{ml}^{-1}$ for $\mathrm{B}$ and $14 \mathrm{mg} \mathrm{ml}^{-1}$ for $\mathrm{I} / \mathrm{II}$. In each case appropriate protein standards were included, as shown by the values for iso-electric point and molecular weight.
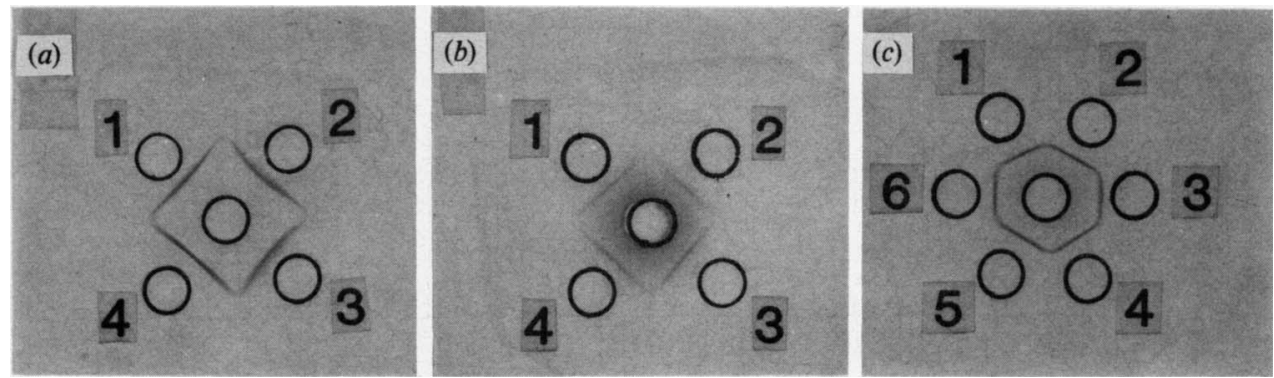

Fig. 4. Comparison of protein preparations by double diffusion. (a) Antiserum to protein $\mathrm{P} 1$ reacting with protein $\mathrm{P} 1$ (1) and (2), antigen I/II (3), and antigen B (4). (b) Antiserum to antigen IF reacting with protein P1 (1) and (2), antigen I/II (3), and antigen B (4). (c) Antiserum to antigen B reacting with protein $\mathrm{Pl}$ (1), (3) and (5); antigen B, (2) and (6); and antigen $\mathrm{I} / \mathrm{II}$ (4).

A serological comparison of P1 with antigens $\mathrm{B}$ and $\mathrm{I} / \mathrm{II}$ by tandem immunodiffusion confirmed a common identity as shown by the confluent lines obtained with anti-P1 (Fig. $4 a$ ), anti-IF (Fig. $4 b$ ) and anti-B (Fig. 4c).

From amino acid analyses of protein P1 (Table 1) it was calculated that the molecule contains approximately 1510 residues with $56.7 \%$ polar and $41.5 \%$ non-polar amino acids; $10.7 \%$ were basic, $26.4 \%$ acidic, and serine and threonine accounted for $15.1 \%$. Cysteine was absent. The preponderance of acidic over basic amino acids accounts for the observed isoelectric point, and the high content of hydroxy-amino acids is consistent with the presence of carbohydrate substitutions joined by $O$-glycosidic linkage. 
Table 1. Amino acid composition of protein PI

$\begin{array}{lcc}\text { Amino acid } & \begin{array}{c}\text { Molar } \\ \text { percentage }\end{array} & \begin{array}{c}\text { Approximate no. } \\ \text { of residues* }\end{array} \\ \text { Lysine } & 8 \cdot 8 & 111 \\ \text { Histidine } & <1.0 & <12 \\ \text { Arginine } & 1.9 & 20 \\ \text { Aspartate } & 13.4 & 186 \\ \text { Threonine } & 8 \cdot 7 & 135 \\ \text { Serine } & 6.4 & 113 \\ \text { Glutamate } & 13.0 & 163 \\ \text { Proline } & 6.6 & 106 \\ \text { Glycine } & 5 \cdot 6 & 138 \\ \text { Alanine } & 12.0 & 249 \\ \text { Valine } & 5 \cdot 6 & 88 \\ \text { Methionine } & 1 \cdot 0 & 12 \\ \text { Isoleucine } & 3.4 & 48 \\ \text { Leucine } & 4.9 & 69 \\ \text { Tyrosine } & 4.5 & 46 \\ \text { Phenylalanine } & 2.3 & 26 \\ \text { Cysteine } & - & -\end{array}$

* Based on a molecular weight of 185000 as determined by SDS-PAGE.
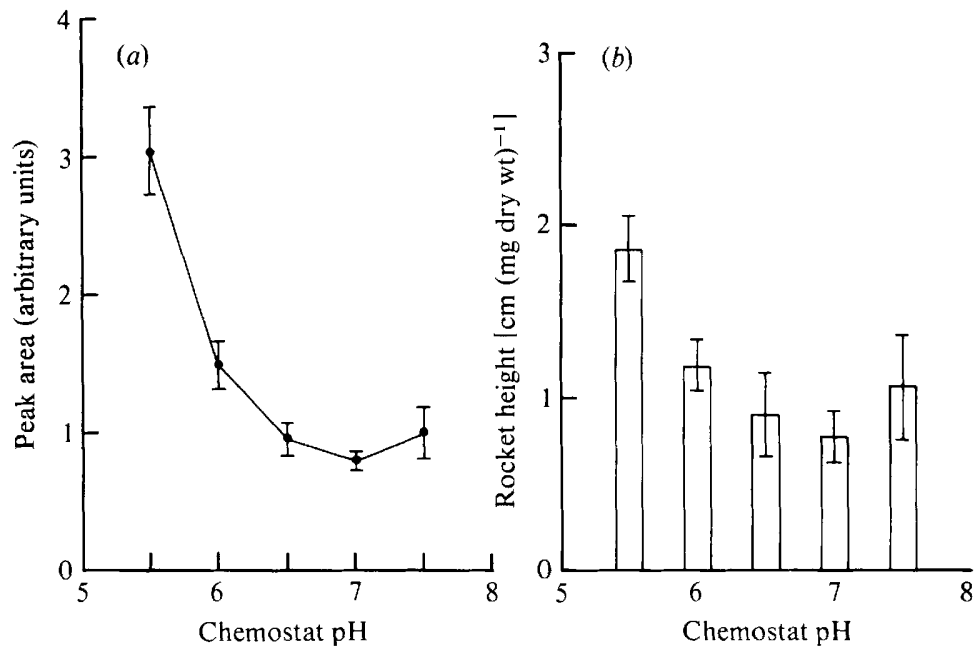

Fig. 5. Estimation of the amounts of protein PI in culture fluid of $S$. mutans Ingbritt grown with fructose-limitation at $D=0 \cdot 1 \mathrm{~h}^{-1}$ and different $\mathrm{pH}$ values. The results for quantitative SDS-PAGE with scanning microdensitometry $(a)$ are averages for at least four determinations and for RIE $(b)$ are averages for at least six determinations. Error bars represent two standard deviations.

\section{Quantification of $P 1$}

Culture fluids from $S$. mutans Ingbritt grown in limiting fructose $(0.5 \%)$ at D $=0.1 \mathrm{~h}^{-1}$ and different $\mathrm{pH}$ values were examined for their content of protein P1 by SDS-PAGE and RIE. By both methods the maximum value was obtained at $\mathrm{pH} 5.5$ and the minimum value at $\mathrm{pH} 7.0$ (Fig. 5). The value by RIE at pH 5.5 was not as great as expected from SDS-PAGE, and this is probably due to the marked decrease in the slope of the line relating rocket height to protein concentration when the rocket height exceeds $1.6-1.8 \mathrm{~cm}$.

In previous studies (Hardy et al., 1981) it was shown that the amounts of P1 detectable by SDS-PAGE increased with an increase in the dilution rate for cultures grown at $\mathrm{pH} 6.0$ with either limiting fructose or sorbitol. These trends have now been confirmed by RIE. 

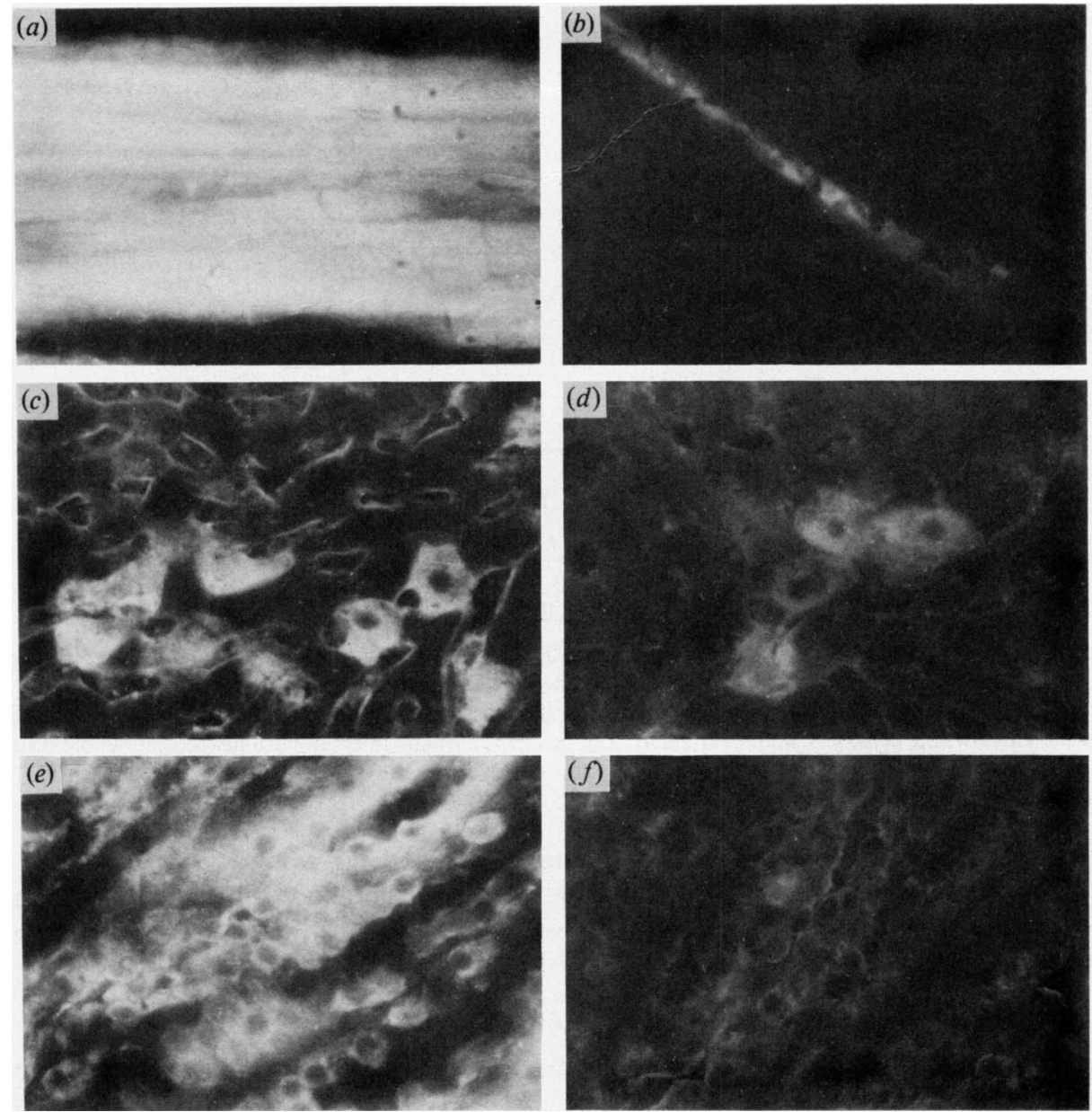

Fig. 6. Detection of reactivity of antiserum to protein Pl with sections of rabbit tissue by two-stage immunofluorescence as described in the text: $(a)$ reaction of heart ventricular muscle: (b) heart ventricular muscle treated with second-stage antibody only; $(c)$ reaction of liver: $(d)$ reaction of liver following absorption of $\mathrm{Pl}$ antiserum with $S$. mutans Ingbritt cell wall; $(e)$ reaction of kidney; $(f)$ reaction of kidney following absorption of $\mathrm{P} 1$ antiserum with $S$. mutans Ingbritt cell wall.

\section{Reactivity of PI antiserum with rabbit tissues}

Sections of tissues from six uninjected rabbits were examined for their reactivity with the IgG fraction from $\mathrm{P} 1$ antiserum, as determined by two-stage immunofluorescence. Heart ventricular muscle, but not valve tissue, showed uniform intense fluorescence (Fig. $6 a$ ) in contrast to the control reaction of fluorescent-labelled sheep anti-rabbit antiserum alone (Fig. $6 b$ ). Liver sections showed evidence of a widespread cytoplasmic reactivity, with occasional cells staining intensely (Fig. $6 c$ ). In addition, the collecting tubules of kidney gave a reaction (Fig. $6 e$ ), and some focal staining occurred throughout brain sections. The reactivity of oral mucosa was restricted to moderate staining of the epithelium, whereas skeletal muscle showed no evidence of binding.

Reaction with 100 -fold diluted IgG was markedly reduced for ventricular muscle and abolished for other tissues. Pre-absorption with Ingbritt cell-wall preparations did not reduce the staining intensity of ventricular muscle but did reduce considerably the intensity of the reaction of other tissues as shown by the result with liver (Fig. $6 d$ ), and kidney (Fig. $6 f$ ). In 


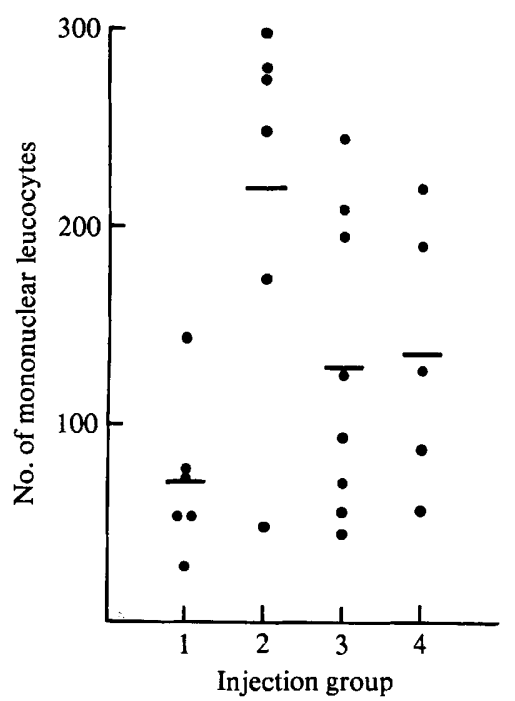

Fig. 7. Numbers of mononuclear leucocytes in sections of rabbit heart muscle: five random fields averaged for three sections; the bars indicate the mean of each group. Group 1, control, uninjected animals; group 2, animals injected with protein P1 ; group 3, animals injected with heat-killed whole cells of $S$. mutans Ingbritt; and group 4, animals injected with heat-killed whole cells of $L$. casei.

control experiments, undiluted rabbit antisera to $L$. casei and egg-white lysozyme reacted very weakly, but no reaction was given after 10-fold dilution. The fluorescent-labelled anti-rabbit antiserum alone reacted with the connective tissue stroma of all tissues, probably because of residual immunoglobulins in blood vessel areas.

\section{Histological study of heart tissue}

The numbers of infiltrated leucocytes in heart sections from four groups of rabbits were counted (Fig. 7). The average for the control group (1) was 71 compared with 220 for the group (2) injected with protein P1, 129 for the group (3) injected with $S$. mutans cells and 136 for the group (4) injected with $L$. casei cells. A statistical analysis of these results by the $t$-test indicated that the increase for P1-injected rabbits was significant at the $1 \%$ level, whereas the increase for the groups injected with whole cells was not significant at the $5 \%$ level.

\section{DISCUSSION}

Studies on monkeys by two independent groups have provided clear evidence of the efficacy of a dental caries vaccine based on specific proteins of $S$. mutans (Lehner et al., 1980, 1982; Russell, R. R. B. et al., 1982, 1983). However, a direct comparison of the results has been limited because of the use of different antigen preparations. The literature on the physico-chemical properties of two of the preparations, namely antigens B (Russell, R. R. B., 1979b) and I/II (Lehner et al., 1980), certainly suggested a close relationship, and the current studies have shown that these two products are indistinguishable from each other and from protein P1.

While the variations in the results obtained with antigen $B$ and $I / I I$ in caries vaccination studies could be due to animal variation and experimental design, there are important questions concerning the purity and stability of such protein preparations. For example, it has proved difficult to remove GTF completely, and more sensitive methods showed that preparations of antigen B used in the early vaccination studies were contaminated with GTF (Russell, R. R. B. et al., 1982). (It should be noted, however, that immunization of monkeys with GTF, per se, does not alter the incidence of caries; Russell, R. R. B. \& Colman, 1981.) The starting material for the current study was chosen with this problem in mind, and it was possible to define growth 
conditions that maximized $P 1$ production but minimized GTF production. The need to monitor the removal of several other contaminating antigens by appropriate quantitative procedures was also considered of prime importance. The stability of the protein antigen is also open to question. Fig. $2 b$ shows that a preparation of P1 stored in solution apparently undergoes degradation, and instability could be the reason for the need to use the two donated preparations, B and I/II, at a considerably higher concentration than P1 in order to obtain bands of comparable intensity on physico-chemical analysis (Fig. 3).

The choice of the immunogen for a caries vaccine requires that there should be no adverse reaction, and antisera to whole cells of $S$. mutans react with human heart tissue (van der Rijn $e t$ al., 1976; Ferretti et al., 1980; Hughes et al., 1980). A direct comparison of results from different laboratories is difficult as the conditions under which organisms are grown can have a marked effect on the amounts of individual surface components, as shown by our own results and those of Russell, R. R. B. et al. (1983) on the production of antigen B (protein P1). Antigen B has also been implicated as one of the components responsible for the cross-reaction on the basis of the evidence presented by Hughes et al. (1980) and Hughes (1981). The present study has confirmed and extended these observations and shown that a variety of tissues will react with antibodies to P1, the strongest reaction being given by heart ventricular muscle. There is the possibility that such a reaction could be indirect and derive from the selective binding of streptococcal antigens to heart tissue (Stinson et al., 1980), though our results were obtained with 'normal' uninjected rabbits. Hughes et al. (1981) concluded from their studies on tissues from germ-free rats that although direct binding of antibodies does occur, there is an enhancement of immunofluorescence if tissues are pre-incubated with several antigen preparations.

Other evidence for $S$. mutans antigens being biologically active includes the pronounced mononuclear infiltration of rabbit heart tissue as a consequence of injection with $S$. mutans cells followed by a solubilized extract of heart tissue (Hughes et al., 1980; Hughes, 1981), and from the current studies, in which the same effect was achieved with a low dose of P1.

While significant signs of disease were not apparent in the above studies in which bacterial products alone were injected, there is a recent, brief report that many of the rabbits injected with disrupted cells of two $S$. mutans strains developed proteinuria, with subsequent weight loss, in addition to having immune deposits in kidney and cardiac muscle (Nisengard et al., 1983). These results, coupled with the above reports on whole cells of $S$. mutans and antigen B (P1) point to the need to test other immunogens for a caries vaccine. Antigen $A$ is a suitable candidate on the basis of its effectiveness in reducing dental caries in experimental animals and the lack of adverse reactions (Russell, R. R. B. et al., 1982; Hughes et al., 1983). It might also be possible to obtain protein fragments of $P 1$ that retain their immunogenicity but no longer produce adverse effects, as has been achieved with M protein of group A haemolytic streptococci (Beachey et al., 1981).

We thank Dr M. Hughes, Professor T. Lehner and Dr R. R. B. Russell for the generous supply of antigens and antisera and for their helpful comments. This work was supported by grant DE 04174 from the National Institute of Dental Research, U.S.A.

\section{REFER ENCES}

Beachey, E. H., Seyer, J. M., Dale, J. B., Simpson, W. A. \& KANG, A. H. (1981). Type-specific protective immunity evoked by synthetic peptide of Streptococcus pyogenes $\mathrm{M}$ protein. Nature, London 292, 457-459.

Campbell, L. K., Knox, K. W. \& Wicken, A. J. (1978). Extractability of cell wall polysaccharide from lactobacilli and streptococci by autoclaving and by dilute acid. Infection and Immunity 22, 842851.

Carlsson, J. (1970). A levansucrase from Streptococcus mutans. Caries Research 4, 97-113.

Closs, O., Harboe, M. \& Wassum, A. M. (1975).
Cross-reactions between mycobacteria. Scandinavian Journal of Immunology (Suppl. 4) 2, 173-185.

COLMAN, G. \& CoHEN, B. (1979). Immunisation of monkeys (Macaca fascicularis) with Streptococcus mutans. In Pathogenic Streptococci, pp. 214-215. Edited by M. T. Parker. Chertsey: Reedbooks.

DischE, Z. (1955). New color reactions for determinations of sugars in polysaccharides. Methods of Biochemical Analysis 2, 313-358.

Ferretti, J. J., Shea, C. \& Humphrey, M. W. (1980). Cross-reactivity of Streptococcus mutans antigens and human heart tissue. Infection and Immunity 30, 69-73. 
Fukui, K., Moriyama, T., Miyake, Y., Mizutani, K. \& TANAKA, O. (1982). Purification and properties of glucosyltransferase responsible for water-insoluble glucan synthesis from Streptococcus mutans. Infection and Immunity 37, 1-9.

GibBons, M. N. (1955). The determination of methyl pentoses. Analyst 80, 268-276.

HARDY, L., JACQues, N. A., Forester, H., CAMPBell, L. K., KNox, K. W. \& WiCKen, A. J. (1981). Effect of fructose and other carbohydrates on the surface properties, lipoteichoic acid production, and extracellular proteins of Streptococcus mutans Ingbritt grown in continuous culture. Infection and Immunity 31, 78-87.

Hughes, M. (1981). Cross-reactions of Streptococcus mutans with heart tissue antigens. In Pathogenic Streptococci, pp. 222-223. Edited by M. T. Parker. Chertsey: Reedbooks.

Hughes, M., Machardy, S. M., Sheppard, A. J. \& Woods, N. C. (1980). Evidence for an immunological relationship between Streptococcus mutans and human cardiac tissue. Infection and Immunity 27, 576-588

Hughes, M., MacHardy, S. M. \& Sheppard, A. J. (1981). Binding of Streptococcus mutans antigens to mammalian cardiac tissue in vitro. Annual Meeting of the British Division of the International Association for Dental Research, Abstract 208.

Hughes, M., Machardy, S. M. \& Sheppard, A. J. (1983). Manufacture and control of a dental caries vaccine for parenteral administration to man. In Chemistry and Biology of Glucosyl Transferases (in the Press). London: Information Retrieval Inc.

Jacques, N. A., Hardy, L., Campbell, L. K., Knox, K. W., Evans, J. D. \& Wicken, A. J. (1979a). Effect of carbohydrate source and growth conditions on the production of lipoteichoic acid by Streptococcus mutans Ingbritt. Infection and Immunity 26, 10791087.

JaCQues, N. A., HARDY, L., KNox, K. W. \& WiCKeN, A. J. $(1979 b)$. Effect of growth conditions on the formation of extracellular lipoteichoic acid by Streptococcus mutans BHT. Infection and Immunity 25, 75-84

JANDA, J. \& WORK, E. (1971). A colorimetric estimation of lipopolysaccharides. FEBS Letters 16, 343 345 .

KNOX, K. W., Forester, H., Hardy, L. \& Wicken, A. J. (1981). Effect of growth conditions on the production of extracellular proteins by oral streptococci. In Basic Concepts of Streptococci and Streptococcal Diseases, pp. 144-145. Edited by S. E. Holm \& P. Christensen. Chertsey: Reedbooks.

Lehner, T., Russell, M. W. \& Caldwell, J. (1980). Immunisation with a purified protein from Streptococcus mutans against dental caries in rhesus monkeys. Lancet 1, 995-996.

Lehner, T., Russell, M. W., Caldwell, J. \& SMith, R. (1982). Immunisation with purified protein antigens from Streptococcus mutans against dental caries in rhesus monkeys. Infection and Immunity 34, $407-415$.
Liljemark, W. F. \& Schauer, S. V. (1975). Studies on the bacterial components which bind Streptococcus sanguis and Streptococcus mutans to hydroxyapatite. Archives of Oral Biology 20, 609-615.

MCCABE, M. M., HameliK, R. M. \& Smith, E. E. (1977). Purification of dextran-binding protein from cariogenic Streptococcus mutans. Biochemical and Physiological Research Communications 78, 273-278.

MCGhee, J. R. \& MichaleK, S. M. (1981). Immunobiology of dental caries: microbial aspects and local immunity. Annual Review of Microbiology 35, 595638.

Mollison, P. L. (1975). Blood transfusion in clinical medicine. Oxford: Blackwell Scientific Publications.

Nisengard, R. J., Stinson, M. W. \& Albini, B. (1983). Kidney and heart pathology in rabbits immunized with Streptococcus mutans. Annual Meeting of the American Association for Dental Research, Abstract 210.

RiJN, I. VAN DER, Bleiweis, A. S. \& ZabriSkie, J. B. (1976). Antigens in Streptococcus mutans crossreactive with human heart muscle. Journal of Dental Research (special issue C) 55, C59-C64.

Russell, M. W. \& LeHNER, T. (1978). Characterisation of antigens extracted from cells and culture fluids of Streptococcus mutans serotype $c$. Archives of Oral Biology 23, 7-15.

Russell, M. W., Bergmeier, L., Zanders, E. D. \& LEHNER, T. (1980). Protein antigens of Streptococcus mutans: purification and properties of a double antigen and its protease resistant component. Infection and Immunity 28, 486-493.

RuSSELL, R. R. B. (1979a). Glucan-binding proteins of Streptococcus mutans serotype c. Journal of General Microbiology 112, 197-201.

Russell, R. R. B. (1979b). Wall-associated protein antigens of Streptococcus mutans. Journal of General Microbiology 114, 109-115.

Russell, R. R. B. \& Colman, G. (1981). Immunisation of monkeys (Macaca fascicularis) with purified Streptococcus mutans glucosyl transferase. Archives of Oral Biology 26, 23-28.

Russell, R. R. B., Beighton, D. \& Cohen, B. (1982). Immunisation of monkeys (Macaca fascicularis) with antigens purified from Streptococcus mutans. British Dental Journal 152, 81-84.

Russell, R. R. B., Peach, S. L., Colman, G. \& CoHEN, B. (1983). Antibody responses to antigens of Streptococcus mutans in monkeys (Macaca fascicularis) immunized against dental caries. Journal of General Microbiology 129, 865-875.

Stinson, M. W., Nisengard, R. J. \& Bergey, E. J. (1980). Binding of streptococcal antigens to muscle tissue in vitro. Infection and Immunity 27, 604-613.

Walker, G. J., Murray, V. L. \& Morrey-Jones, J. G. (1980). Regulation of dextranase synthesis by Streptococcus mutans. FEBS Letters 115, 206-208.

ZANDERS, E. D. \& Lehner, T. (1981). Separation and characterization of a protein antigen from cells of Streptococcus mutans. Journal of General Microbiology 122, 217-225. 